\title{
Supporting Information: Ammine Magnesium Borohydride Nanocomposites for All-Solid-State Magnesium Batteries
}

\author{
Yigang Yan, ${ }^{1,2,3}$ Jakob B. Grinderslev, ${ }^{1}$ Mathias Jørgensen, ${ }^{1}$ Lasse N. Skov, ${ }^{1}$ \\ Jørgen Skibsted, ${ }^{1}$ Torben R. Jensen ${ }^{1 *}$
}

${ }^{1}$ Interdisciplinary Nanoscience Center (iNANO) and Department of Chemistry

Aarhus University, Langelandsgade 140, 8000 Aarhus C, Denmark.

E-mail: trj@chem.au.dk

${ }^{2}$ Institute of New Energy and Low-Carbon Technology, Sichuan University

Chengdu 610207, China.

${ }^{3}$ Engineering Research Center of Sustainable Energy Materials and Devices, Ministry of Education, Chengdu 610065, China. 

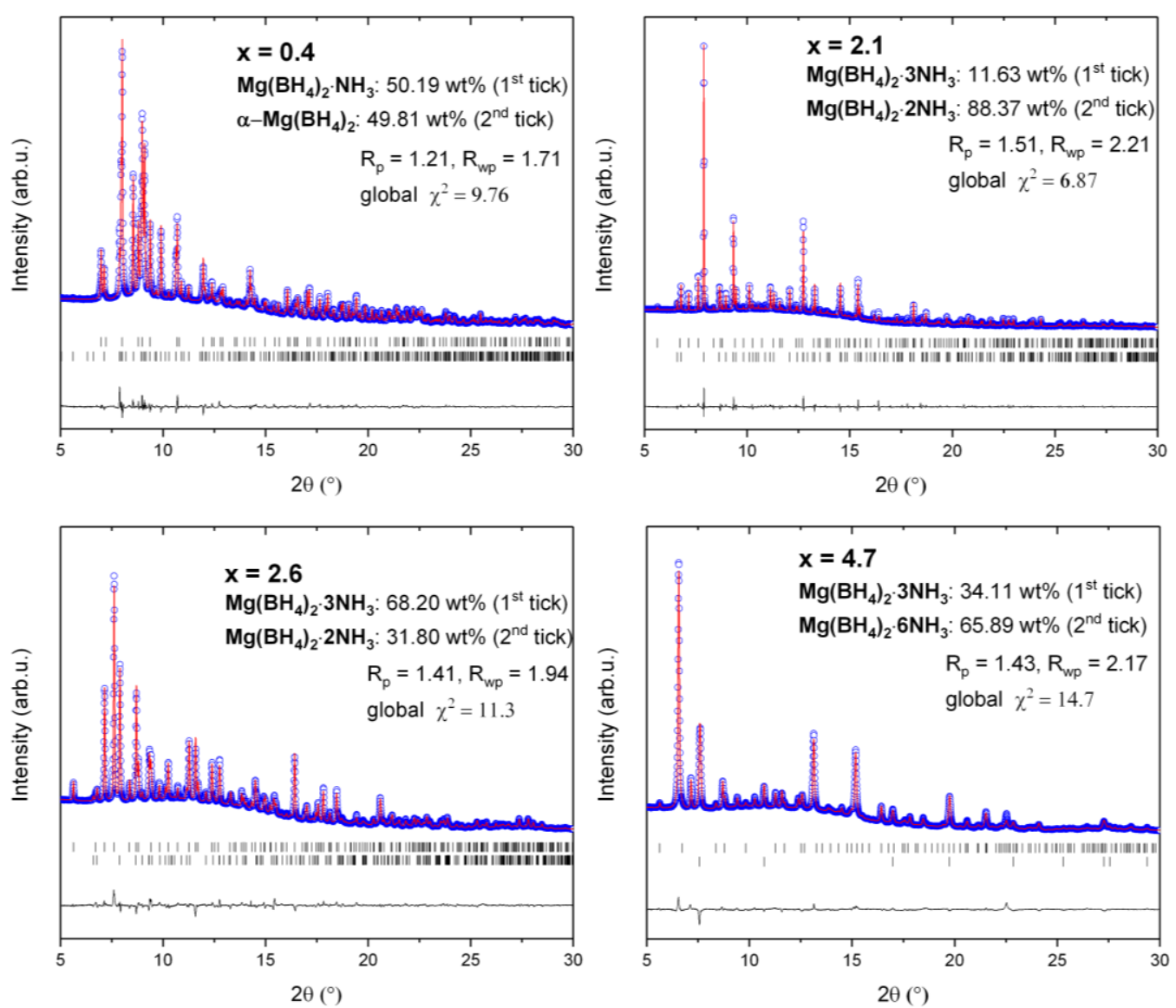

Figure S1. Rietveld refinement plot of PXD data measured at room temperature, $\lambda=0.708481$ $\AA$, for $\mathrm{Mg}\left(\mathrm{BH}_{4}\right)_{2} \cdot x \mathrm{NH}_{3}(\mathrm{x}=0.4,2.1,2.6,4.7)$, showing experimental (blue circles) and calculated (red line) PXD patterns, and a difference plot below (black line). Final discrepancy factors, $\mathrm{R}_{\mathrm{p}}$ and $\mathrm{R}_{\mathrm{wp}}$ (not corrected for background), and global $\chi^{2}$ are shown. $\alpha-\mathrm{Mg}\left(\mathrm{BH}_{4}\right)_{2}$ : space group $P 6_{1} 22$, unit cell parameters $a=10.3540(12), c=37.055(4) \AA$. 

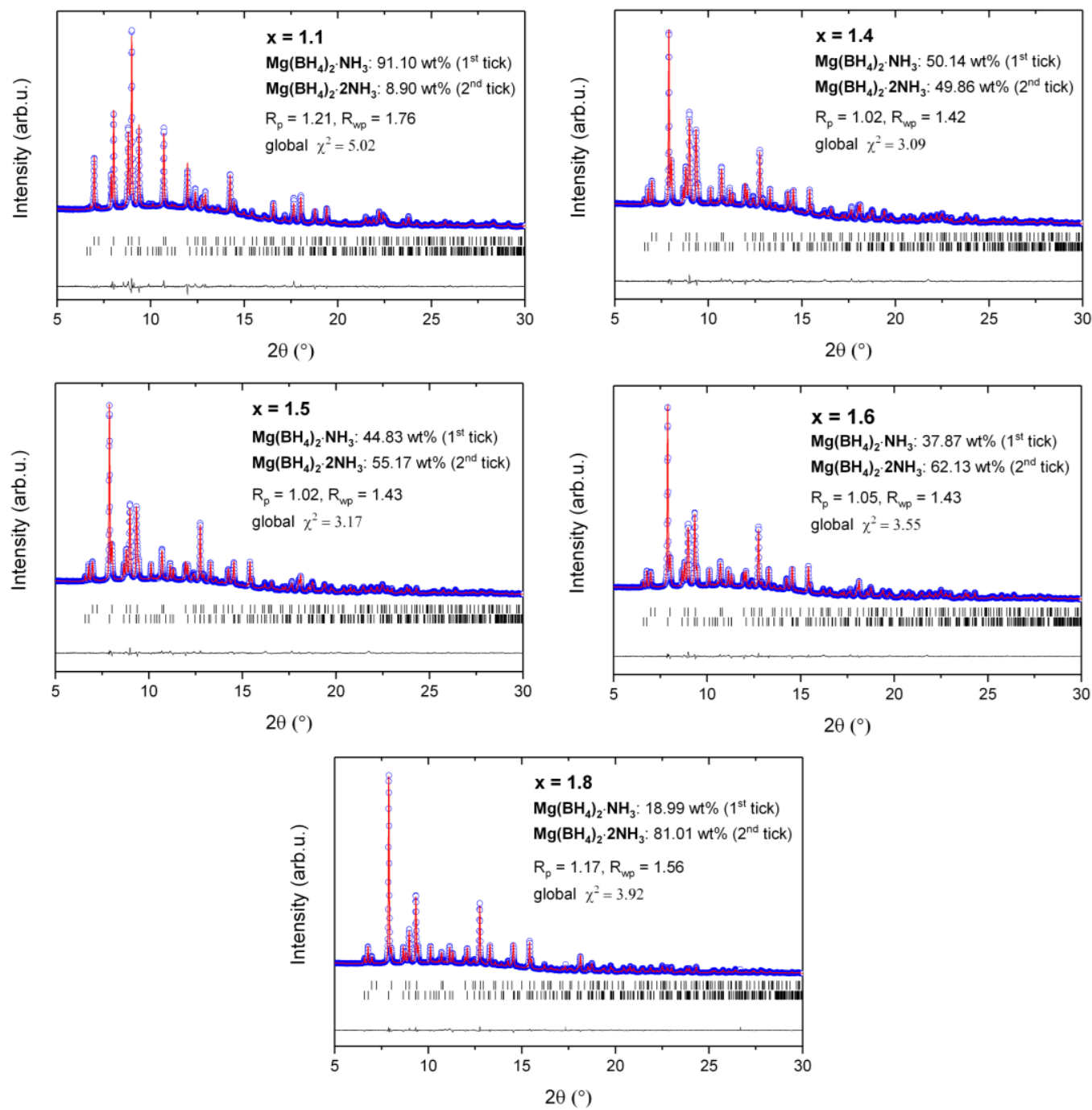

Figure S2. Rietveld refinement plot of PXD data measured at room temperature, $\lambda=0.708481$ $\AA$, for $\mathrm{Mg}\left(\mathrm{BH}_{4}\right)_{2} \cdot x \mathrm{NH}_{3}(\mathrm{x}=1.1,1.4,1.5,1.6,1.8)$, showing experimental (blue circles) and calculated (red line) PXD patterns, and a difference plot below (black line). Final discrepancy factors, $R_{p}$ and $R_{w p}$ (not corrected for background), and global $\chi^{2}$ are shown. 


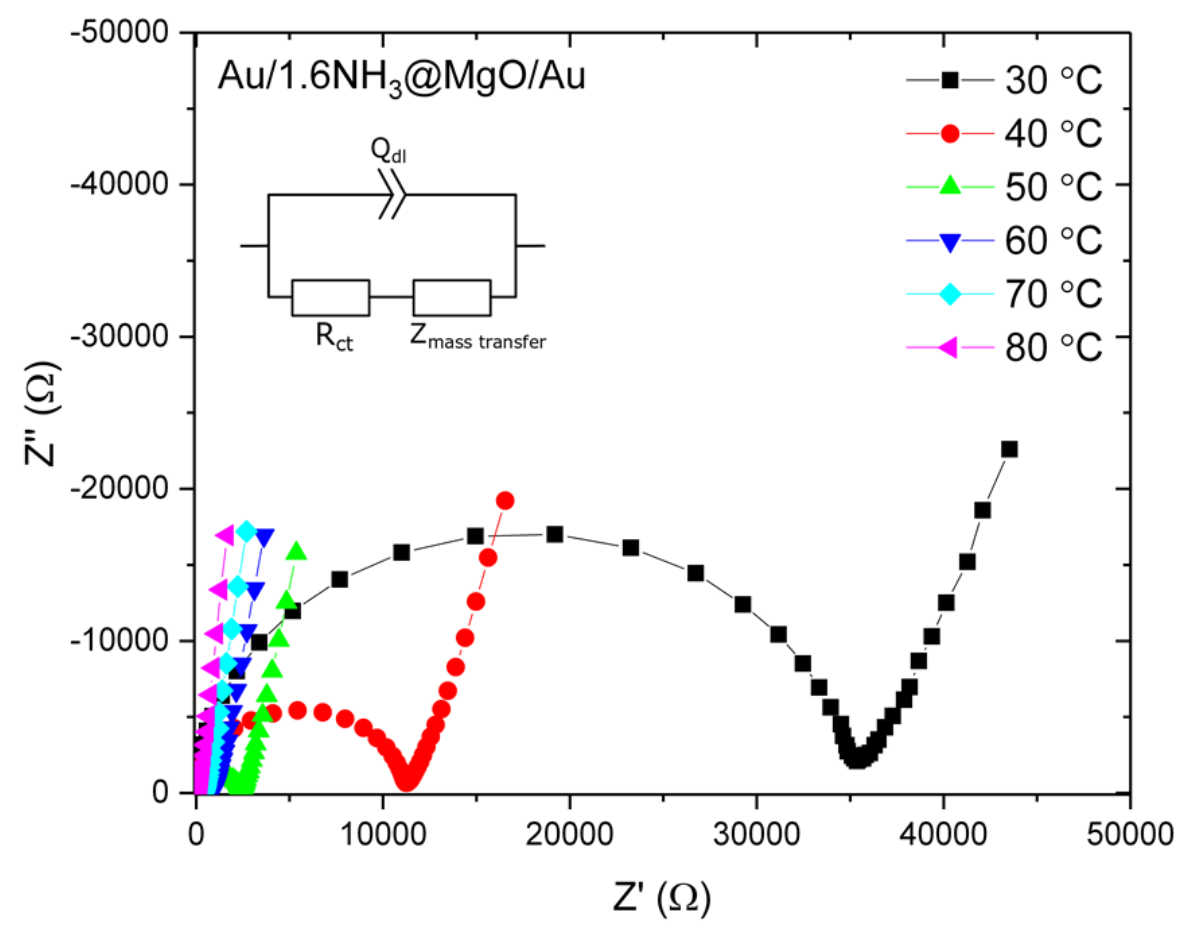

Figure S3. Nyquist plots for AC-EIS measurement on the nanocomposite 1.6 $\mathrm{NH}_{3} @ \mathrm{MgO}$ using $\mathrm{Au}$ as block electrode.

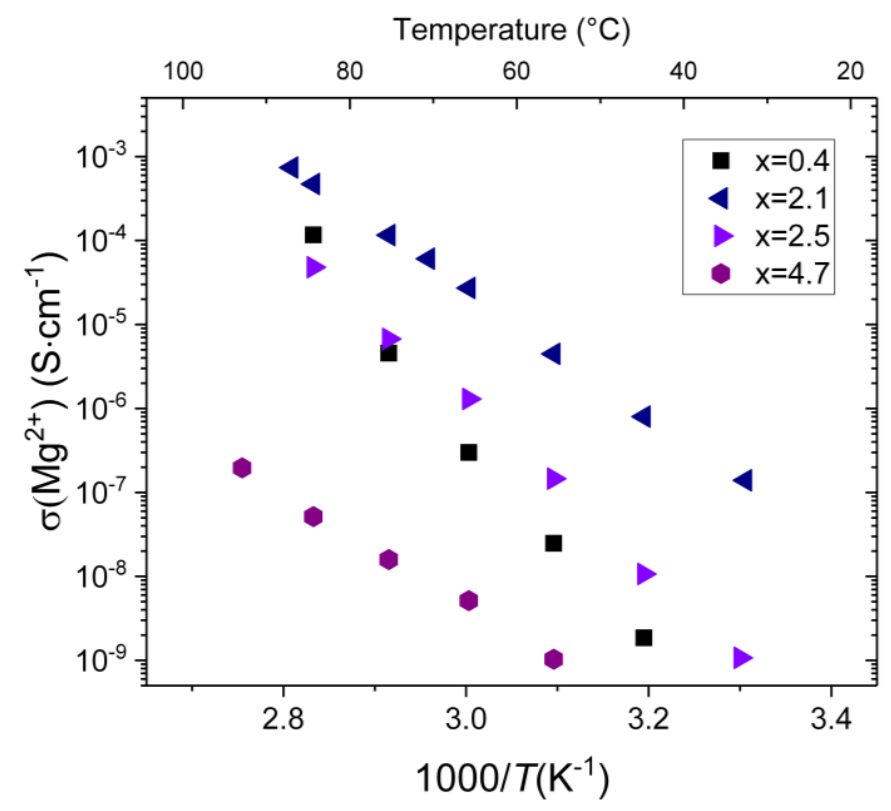

Figure S4. Temperature dependent ionic conductivity of $\mathrm{Mg}\left(\mathrm{BH}_{4}\right)_{2} \cdot x \mathrm{NH}_{3}, x=0.4,2.1$, and 4.7. 


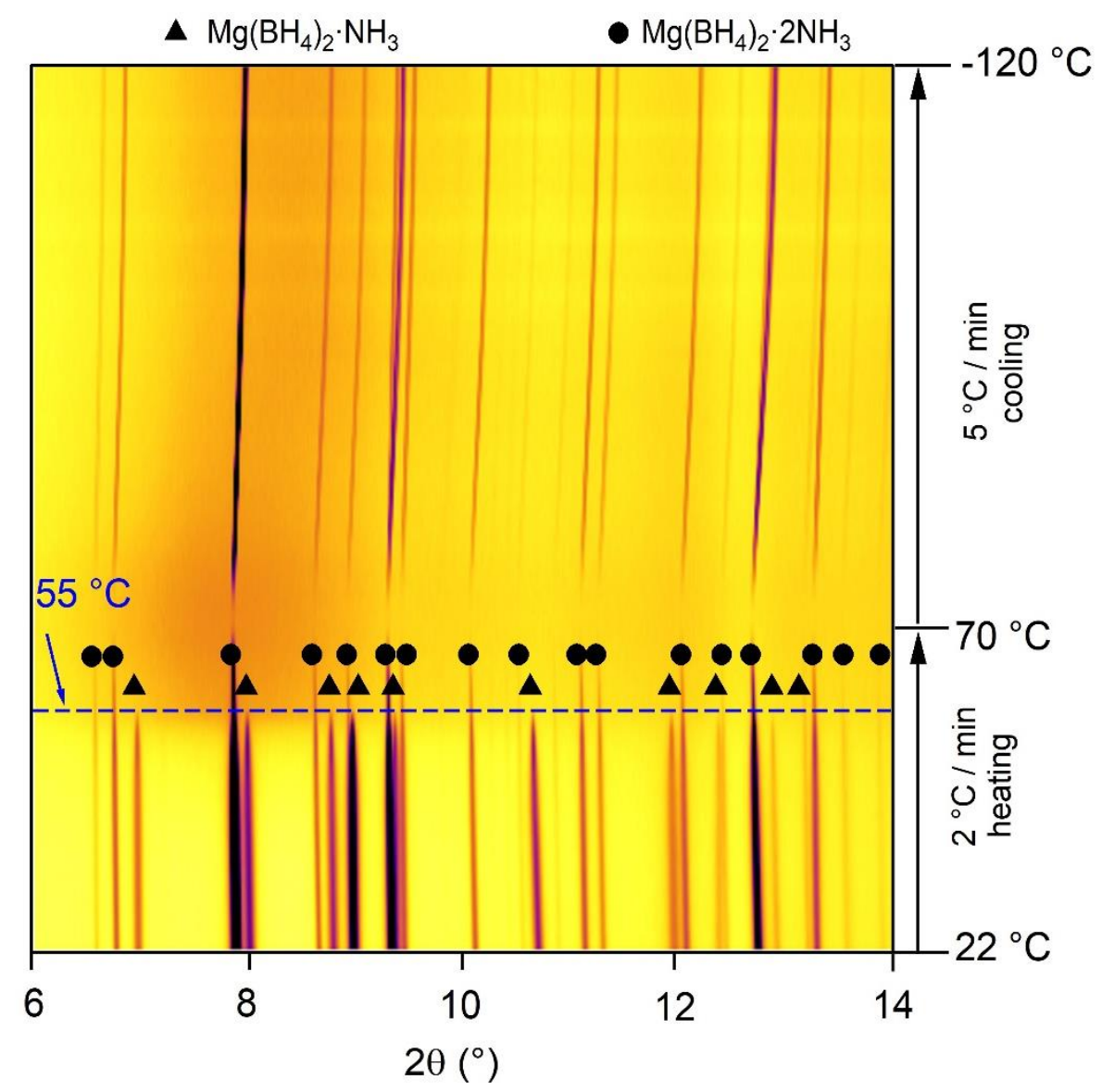

Figure S5. In situ SR PXD pattern of $\mathrm{Mg}\left(\mathrm{BH}_{4}\right)_{2} \cdot 1.6 \mathrm{NH}_{3}$ heated from 22 to $70{ }^{\circ} \mathrm{C}(\Delta T / \Delta t=$ $\left.2{ }^{\circ} \mathrm{C} / \mathrm{min}\right)$ and subsequently cooled to $-120{ }^{\circ} \mathrm{C}\left(\Delta T / \Delta t=5{ }^{\circ} \mathrm{C} / \mathrm{min}, \lambda=0.708481 \AA\right.$ ). During heating, reflections from $\mathrm{Mg}\left(\mathrm{BH}_{4}\right)_{2} \cdot \mathrm{NH}_{3}$ disappear at $55{ }^{\circ} \mathrm{C}$, while reflections from $\mathrm{Mg}\left(\mathrm{BH}_{4}\right)_{2} \cdot 2 \mathrm{NH}_{3}$ decrease in intensity, corresponding to the eutectic melting of $\mathrm{Mg}\left(\mathrm{BH}_{4}\right)_{2} \cdot 1.5 \mathrm{NH}_{3}$ (i.e. composition $0.5 \mathrm{Mg}\left(\mathrm{BH}_{4}\right)_{2} \cdot \mathrm{NH}_{3}-0.5 \mathrm{Mg}\left(\mathrm{BH}_{4}\right)_{2} \cdot 2 \mathrm{NH}_{3}$ ). The remaining reflections from excess $\mathrm{Mg}\left(\mathrm{BH}_{4}\right)_{2} \cdot 2 \mathrm{NH}_{3}$ disappear at $70{ }^{\circ} \mathrm{C}$ due to melting. Upon cooling the reflections from excess $\mathrm{Mg}\left(\mathrm{BH}_{4}\right)_{2} \cdot 2 \mathrm{NH}_{3}$ reappear. Reflections from $\mathrm{Mg}\left(\mathrm{BH}_{4}\right)_{2} \cdot \mathrm{NH}_{3}$ were not observed during cooling, indicating the amorphization of the eutectic melt consisting of $0.5 \mathrm{Mg}\left(\mathrm{BH}_{4}\right)_{2} \cdot \mathrm{NH}_{3}$ and $0.5 \mathrm{Mg}\left(\mathrm{BH}_{4}\right)_{2} \cdot 2 \mathrm{NH}_{3}$. 

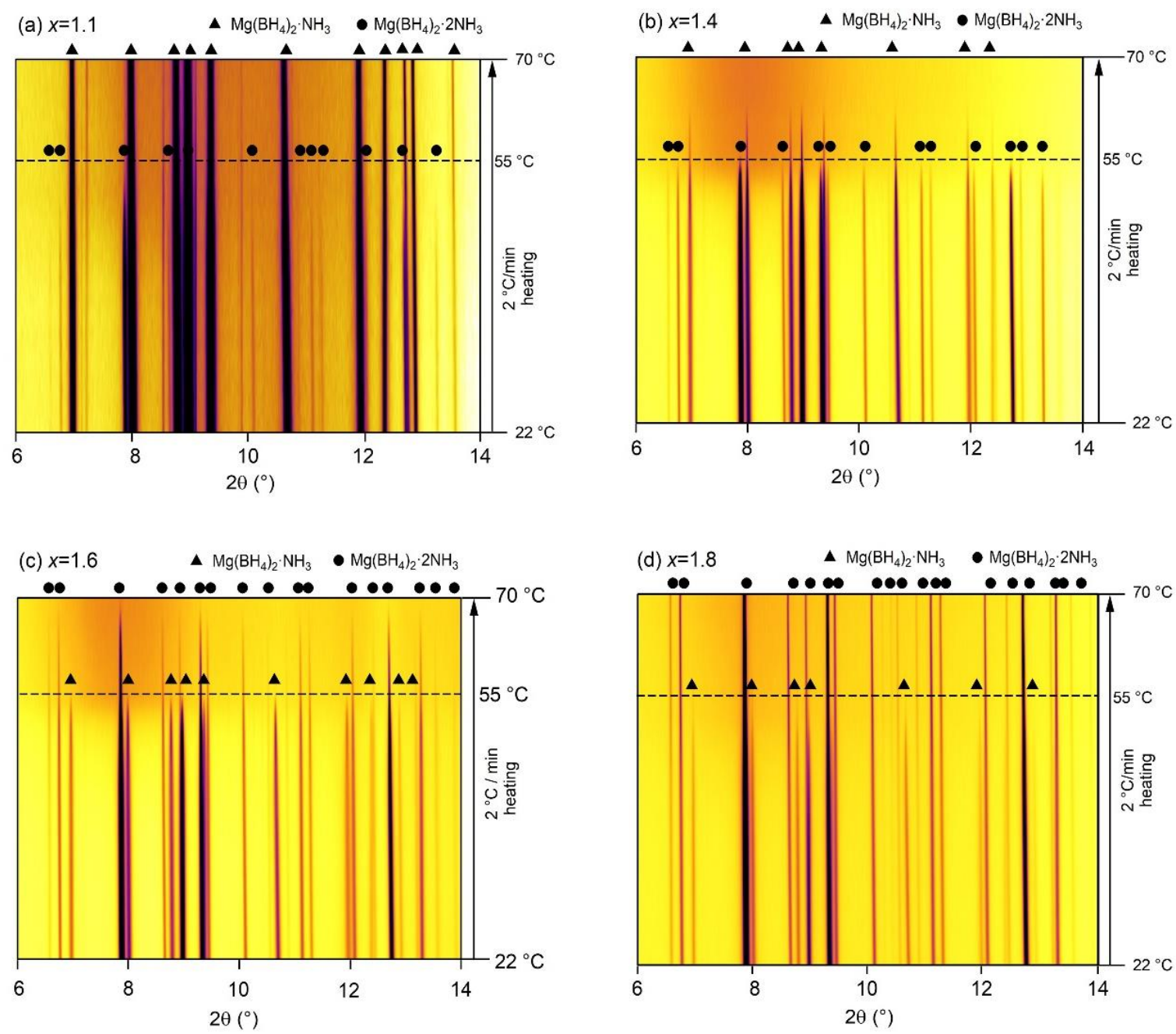

Figure S6. In situ SR PXD pattern of $\mathrm{Mg}\left(\mathrm{BH}_{4}\right)_{2} \cdot x \mathrm{NH}_{3}$. A. $x=1.1, \mathrm{~B}: x=1.4, \mathrm{C}: x=1.6, \mathrm{D}$ : $1.8(\lambda=0.708481 \AA)$. For $x=1.1$ and $x=1.4$, the reflections of $\operatorname{Mg}\left(\mathrm{BH}_{4}\right)_{2} \cdot 2 \mathrm{NH}_{3}$ disappear at $55{ }^{\circ} \mathrm{C}$ upon heating, owing to eutectic melting of the composition $0.5 \mathrm{Mg}\left(\mathrm{BH}_{4}\right)_{2} \cdot \mathrm{NH}_{3}-$ $0.5 \mathrm{Mg}\left(\mathrm{BH}_{4}\right)_{2} \cdot 2 \mathrm{NH}_{3}$, while reflections from $\mathrm{Mg}\left(\mathrm{BH}_{4}\right)_{2} \cdot \mathrm{NH}_{3}$ remain visible. For $x=1.6$ and $x=$ 1.8 the reflections of $\mathrm{Mg}\left(\mathrm{BH}_{4}\right)_{2} \cdot \mathrm{NH}_{3}$ disappear at $55^{\circ} \mathrm{C}$ upon heating, again owing to eutectic melting of the composition $0.5 \mathrm{Mg}\left(\mathrm{BH}_{4}\right)_{2} \cdot \mathrm{NH}_{3}-0.5 \mathrm{Mg}\left(\mathrm{BH}_{4}\right)_{2} \cdot 2 \mathrm{NH}_{3}$, while reflections from $\mathrm{Mg}\left(\mathrm{BH}_{4}\right)_{2} \cdot 2 \mathrm{NH}_{3}$ remain visible. These observations consistently indicate the occurrence of eutectic melting of the composition $0.5 \mathrm{Mg}\left(\mathrm{BH}_{4}\right)_{2} \cdot \mathrm{NH}_{3}-0.5 \mathrm{Mg}\left(\mathrm{BH}_{4}\right)_{2} \cdot 2 \mathrm{NH}_{3}$ at $55{ }^{\circ} \mathrm{C}$ for $\mathrm{x} \approx$ 1.5, i.e. $\mathrm{Mg}\left(\mathrm{BH}_{4}\right)_{2} \cdot 1.5 \mathrm{NH}_{3}$. 


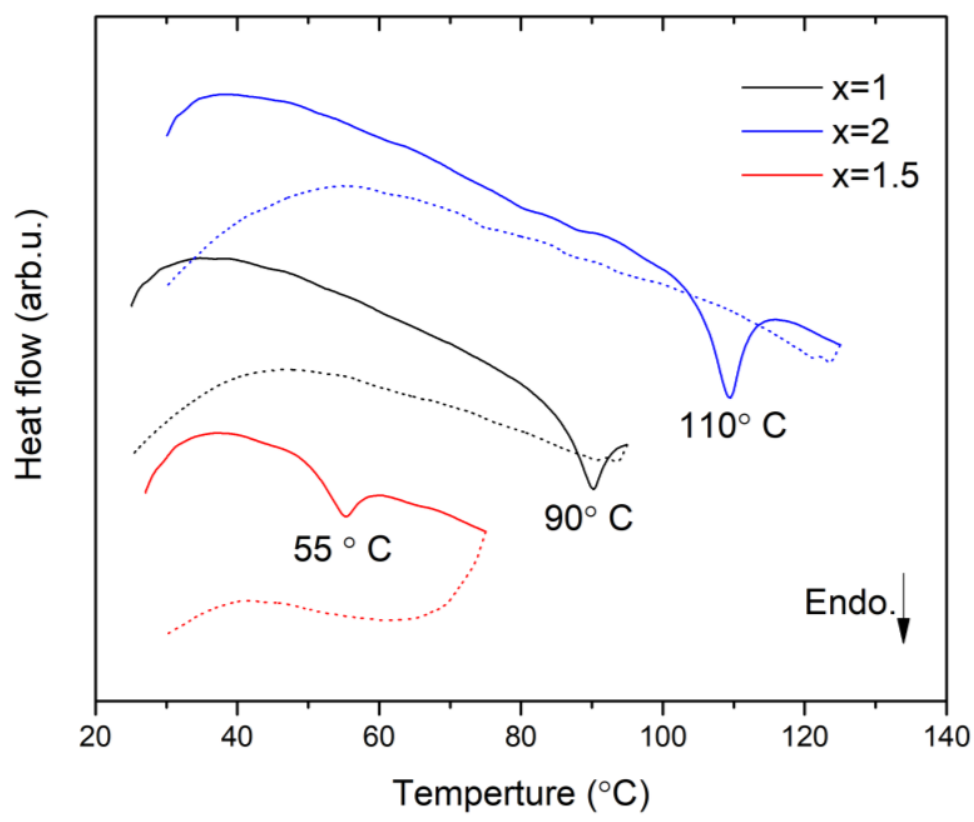

Figure S7. DSC profiles of sample $\mathrm{Mg}\left(\mathrm{BH}_{4}\right)_{2} \cdot x \mathrm{NH}_{3}(x=1,1.5,2)$ measured in an Ar flow ( 50 $\mathrm{mL} / \mathrm{min}$ ) with a heating rate of $\Delta T / \Delta t=5^{\circ} \mathrm{C} / \mathrm{min}$.

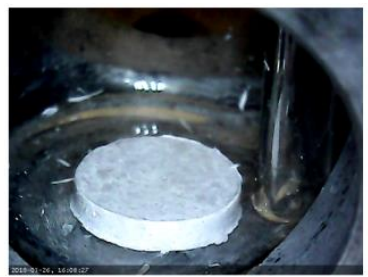

$30{ }^{\circ} \mathrm{C}$

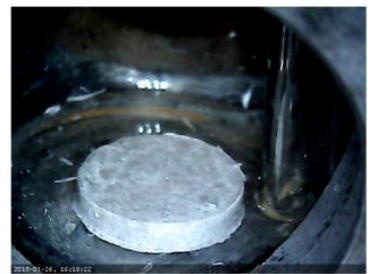

$50^{\circ} \mathrm{C}$

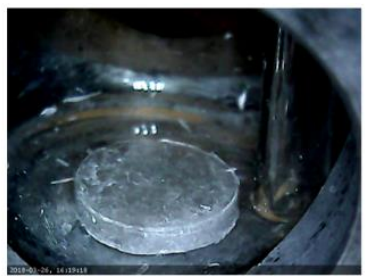

$60^{\circ} \mathrm{C}$

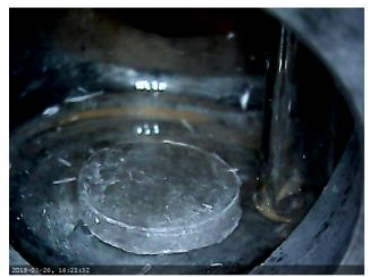

$70^{\circ} \mathrm{C}$

Figure S8. Photographic inspection of $\mathrm{Mg}\left(\mathrm{BH}_{4}\right)_{2} \cdot 1.5 \mathrm{NH}_{3}$ during heating from 30 to $70{ }^{\circ} \mathrm{C}$, where the pellet keeps the shape. 


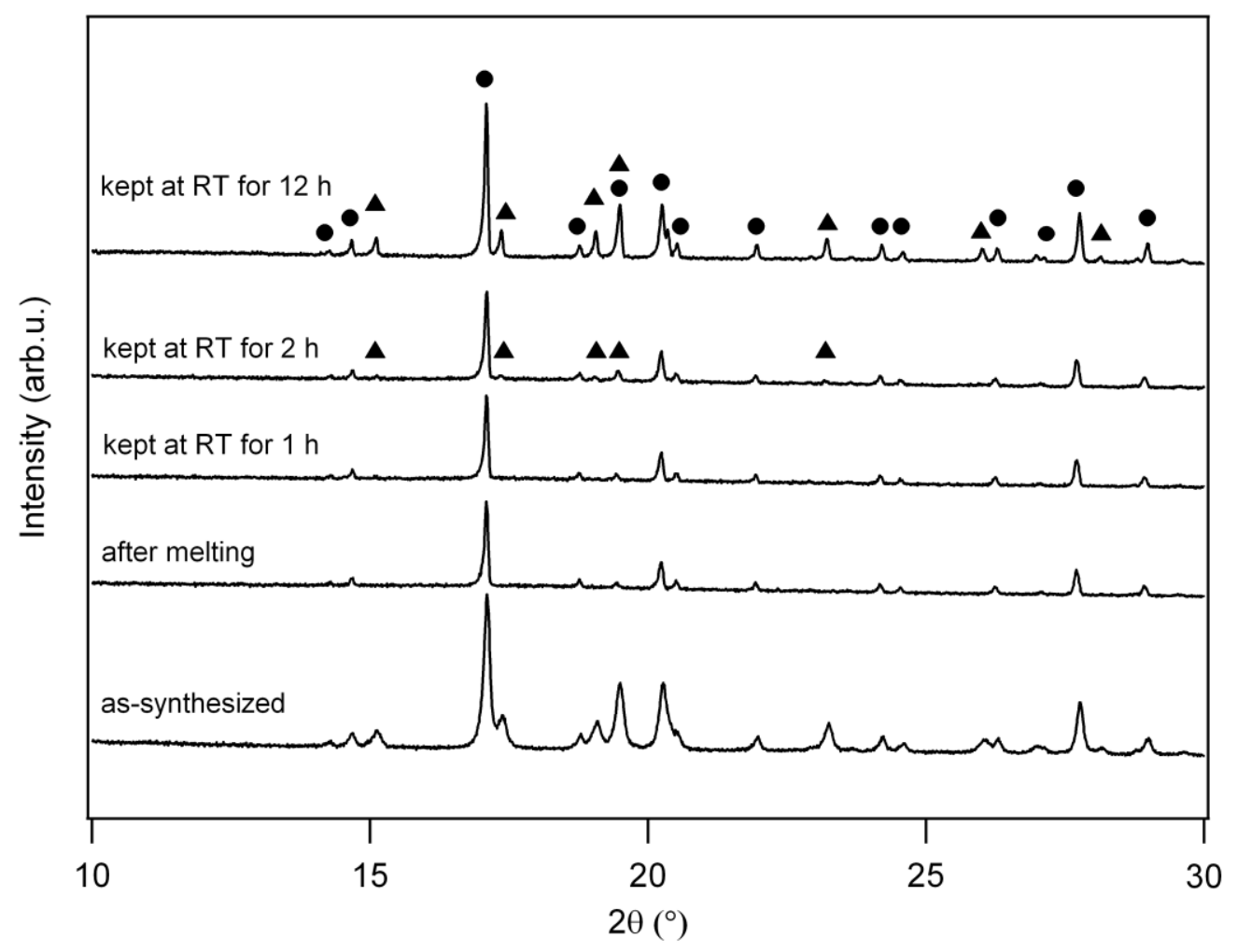

Figure S9. PXD patterns of the as-synthesized composite $x=1.6$, the composite $x=1.6$ after melting at $70{ }^{\circ} \mathrm{C}$, the melt of $x=1.6$ after being kept at RT for $1 \mathrm{~h}, 2 \mathrm{~h}$, and $12 \mathrm{~h}$, respectively.

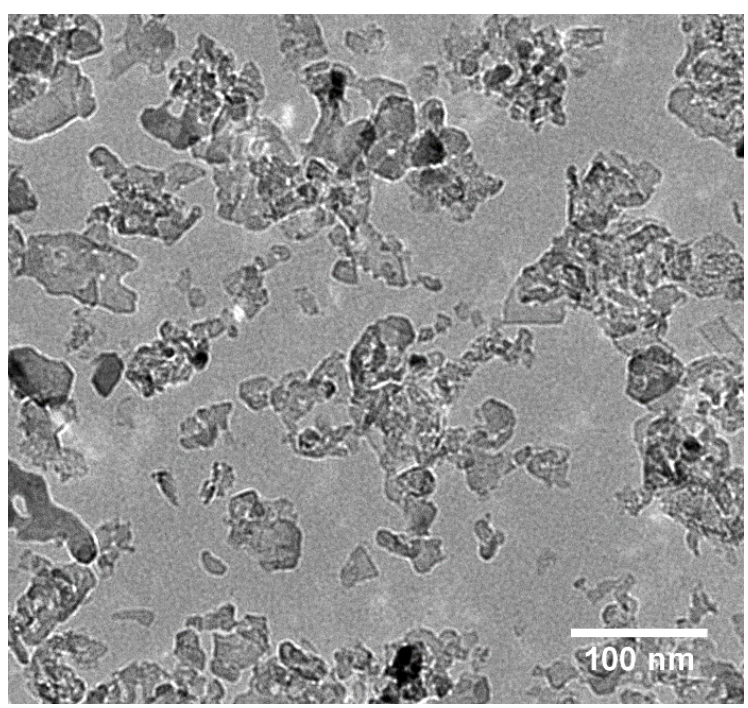

Figure S10. Transmission electron microscopy (TEM) image of $\mathrm{MgO}$ nanopowders. $\mathrm{MgO}$ nanopowders show partial agglomeration and random shape with particle sizes from 10 to 50 nm. 


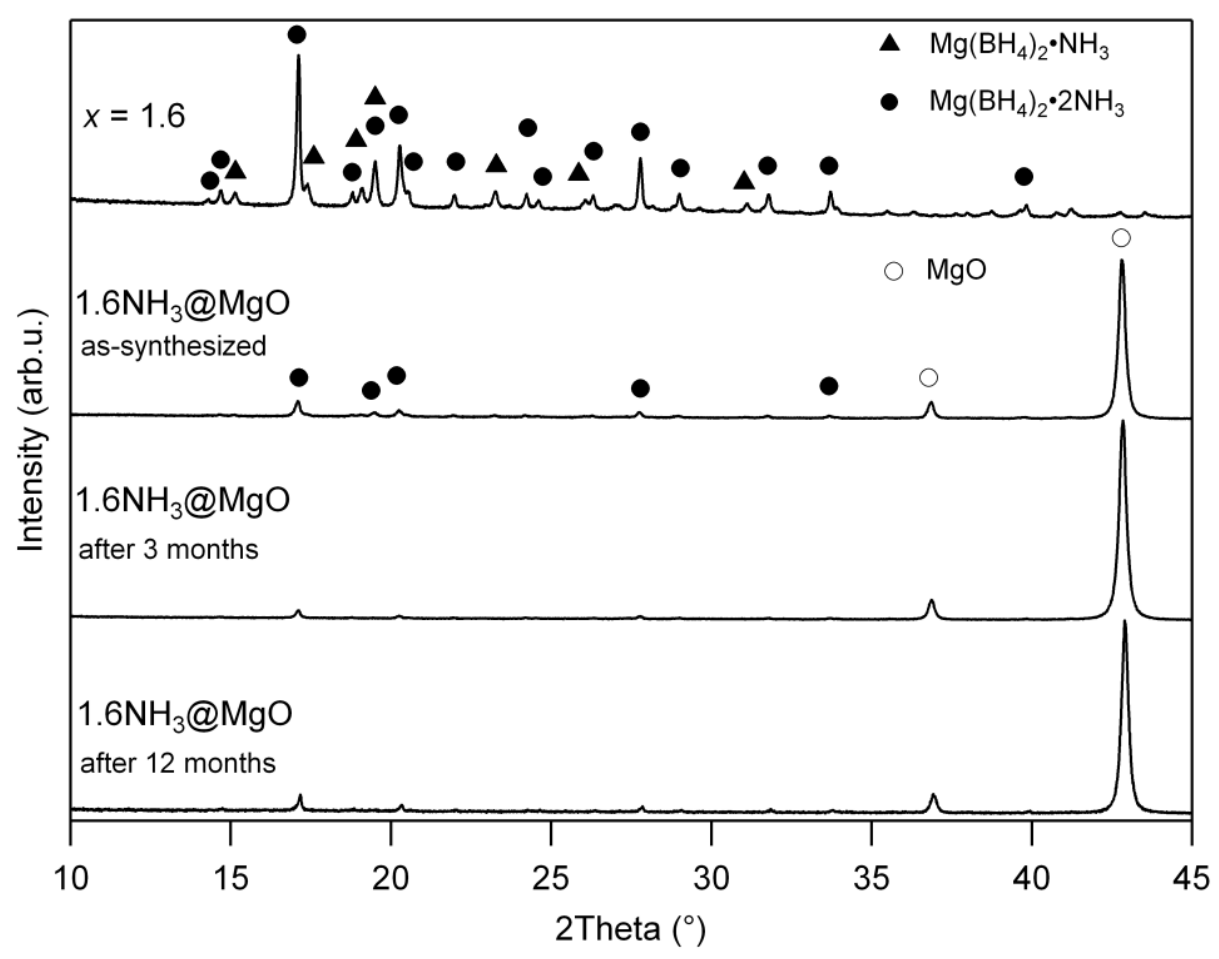

Figure S11. PXD patterns of composite $x=1.6$, the as-synthesized nanocomposite 1.6 $\mathrm{NH}_{3} @ \mathrm{MgO}$ and the nanocomposite 1.6 $\mathrm{NH}_{3} @ \mathrm{MgO}$ after storage in glove box for 3 and 12 months.

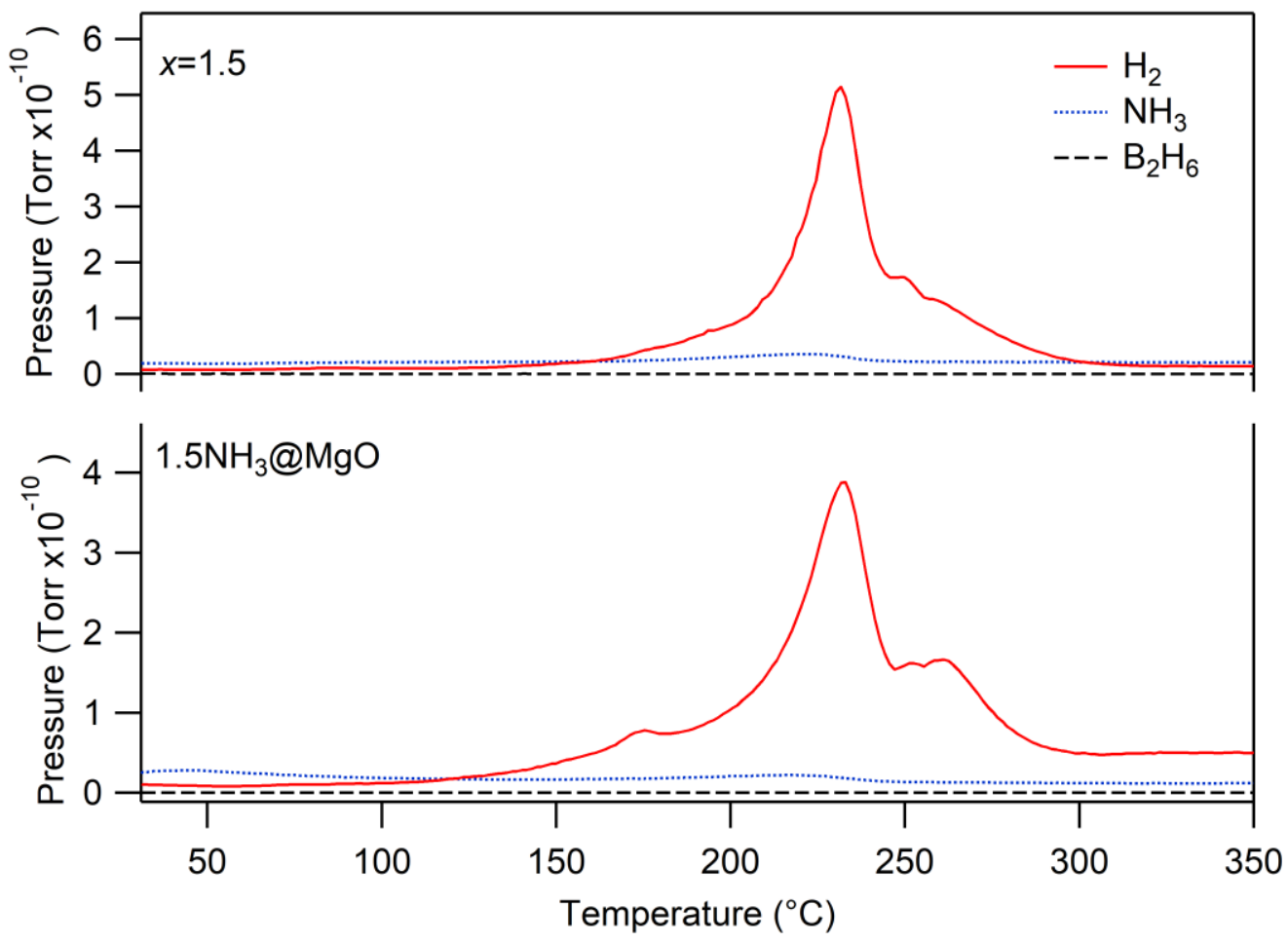

Figure S12. Mass spectrometry of $\mathrm{Mg}\left(\mathrm{BH}_{4}\right)_{2} \cdot 1.5 \mathrm{NH}_{3}$ (i.e. $\left.x=1.5\right)$ and $1.5 \mathrm{NH}_{3} @ \mathrm{MgO}(\mathrm{Ar}$ flow, $50 \mathrm{~mL} / \mathrm{min}$, heat rate $5{ }^{\circ} \mathrm{C} / \mathrm{min}$ ). The results indicate that the onset decomposition temperatures are around $120{ }^{\circ} \mathrm{C}$ for sample $x=1.5$ and $1.5 \mathrm{NH}_{3} @ \mathrm{MgO}$. 


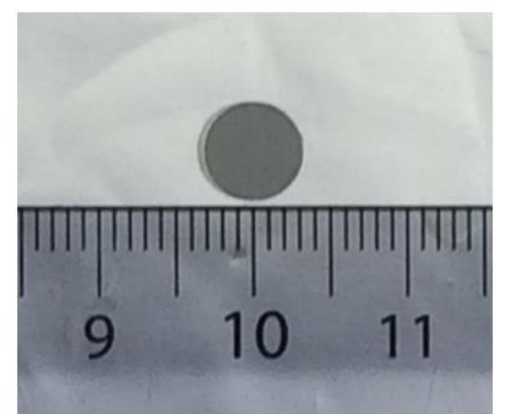

Before heating

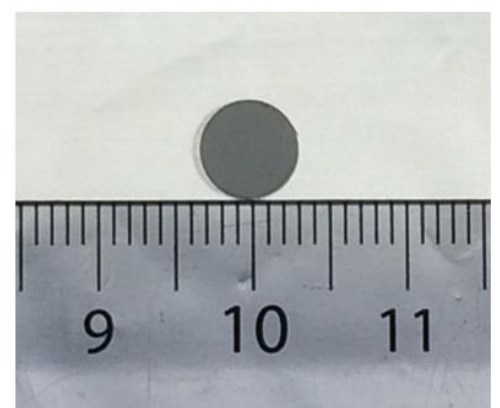

After heating

Figure S13. A 1.6 $\mathrm{NH}_{3} @ \mathrm{MgO}$ pellet before (left) and after (right) being heated at $200{ }^{\circ} \mathrm{C}$ in air for 30 mins. No deformation of the pellet was observed after heating. 

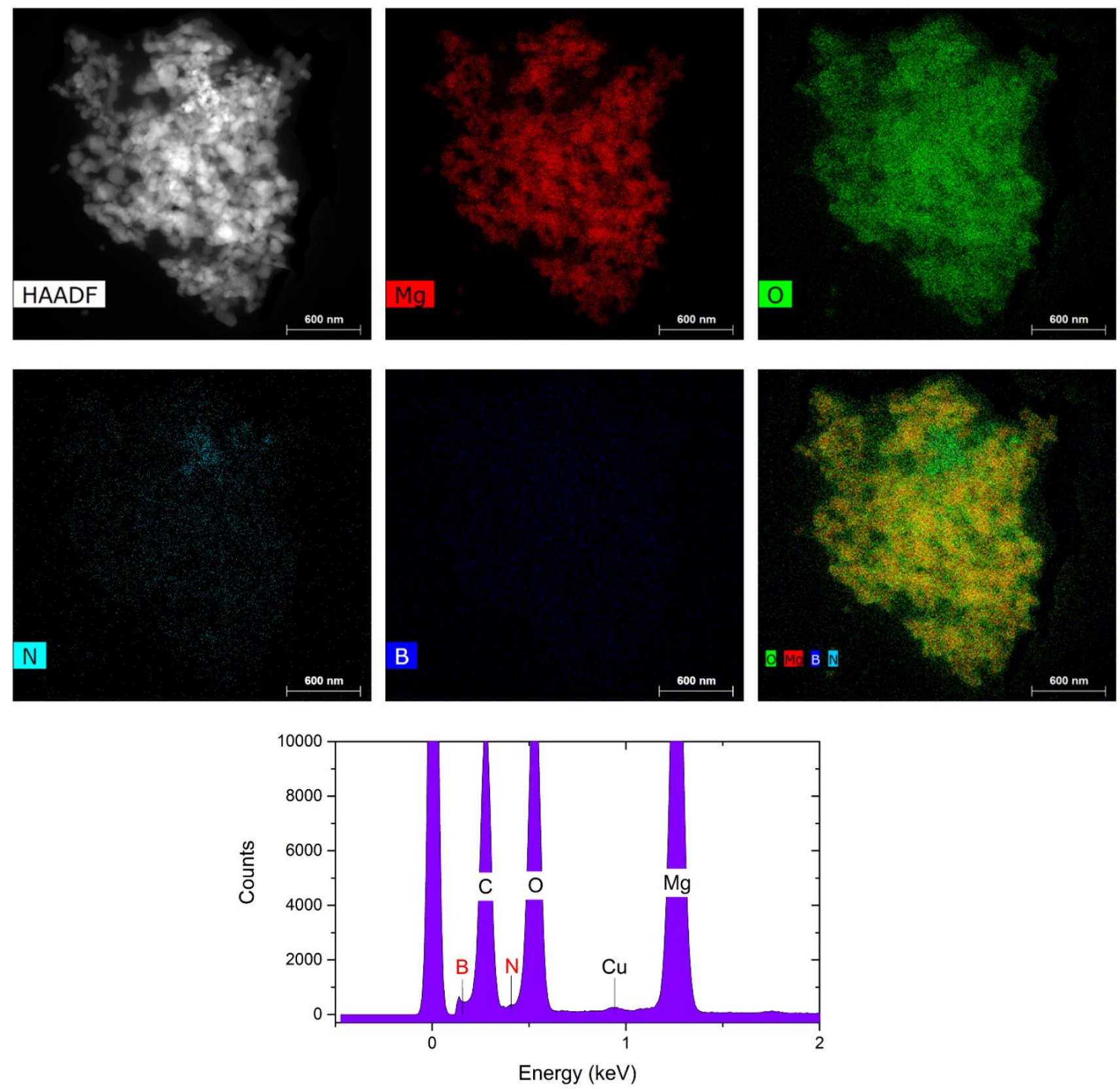

Figure S14. Scanning transmission electron microscopy (STEM) image and energy-dispersive X-ray spectroscopy (EDS) of 1.6 $\mathrm{NH}_{3} @ \mathrm{MgO}$ nanocomposite. STEM images confirms an even distribution of $\mathrm{B}$ and $\mathrm{N}$ originating from the compounds $\mathrm{Mg}\left(\mathrm{BH}_{4}\right)_{2} \cdot \mathrm{NH}_{3}$ and $\mathrm{Mg}\left(\mathrm{BH}_{4}\right)_{2} \cdot 2 \mathrm{NH}_{3}$ in the nanocomposite $\mathrm{Mg}\left(\mathrm{BH}_{4}\right)_{2} \cdot 1.6 \mathrm{NH}_{3}-\mathrm{MgO}(75 \mathrm{wt} \%)$. 


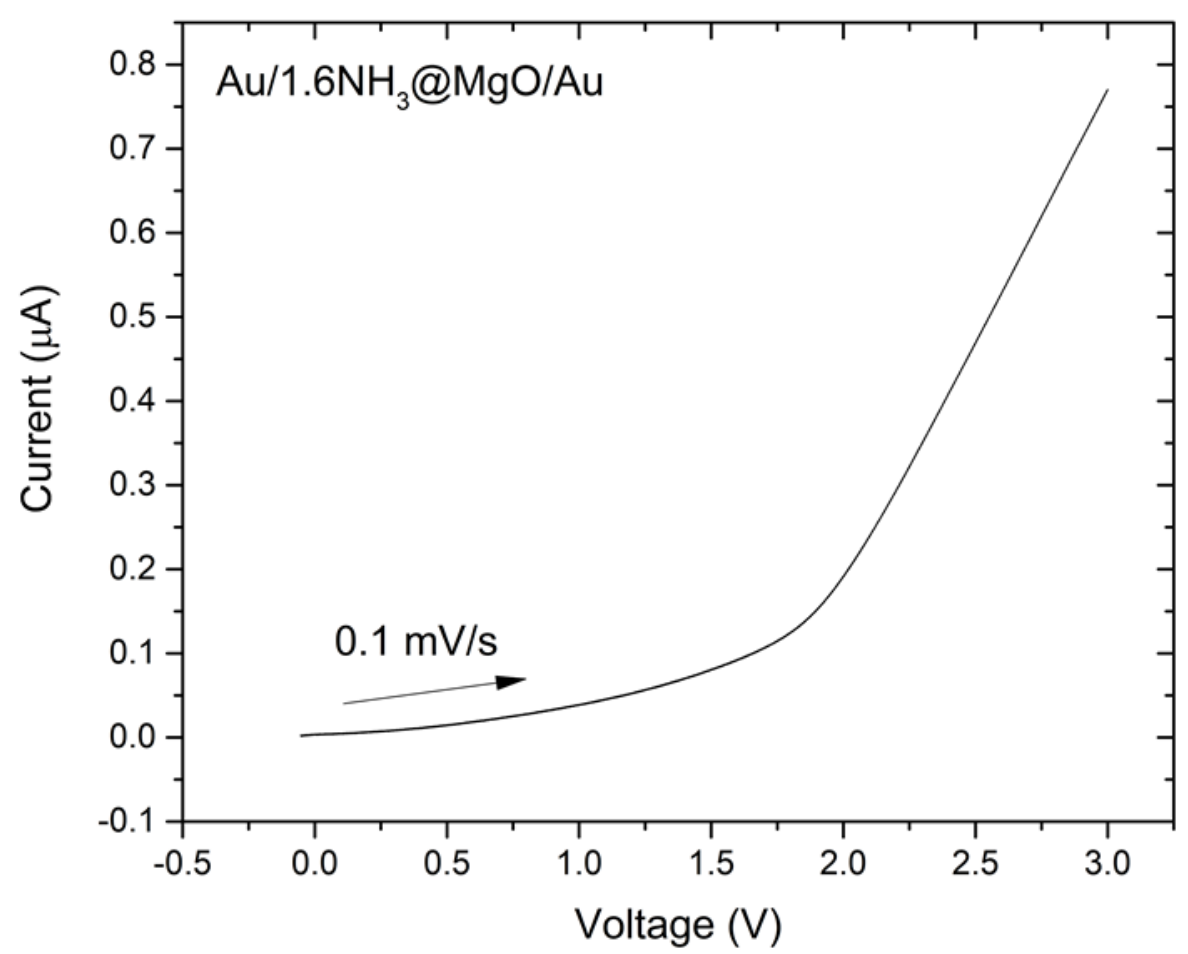

Figure S15. Cyclic voltammogram of an $\mathrm{Au}\left|1.6 \mathrm{NH}_{3} @ \mathrm{MgO}\right| \mathrm{Au}$ cell at $25{ }^{\circ} \mathrm{C}$ (pellet size: 0.5 $\mathrm{mm}$ in thickness and $6.4 \mathrm{~mm}$ in diameter). Linear fitting between 0 and $1.0 \mathrm{~V}$ of a symmetric $\mathrm{Au}\left|1.6 \mathrm{NH}_{3} @ \mathrm{MgO}\right| \mathrm{Au}$ cell provides a resistance of $4.2 \times 10^{7} \Omega$, corresponding to an electronic conductivity of $\sigma_{\mathrm{e}}=3.9 \times 10^{-9} \mathrm{~S} \mathrm{~cm}^{-1}$.

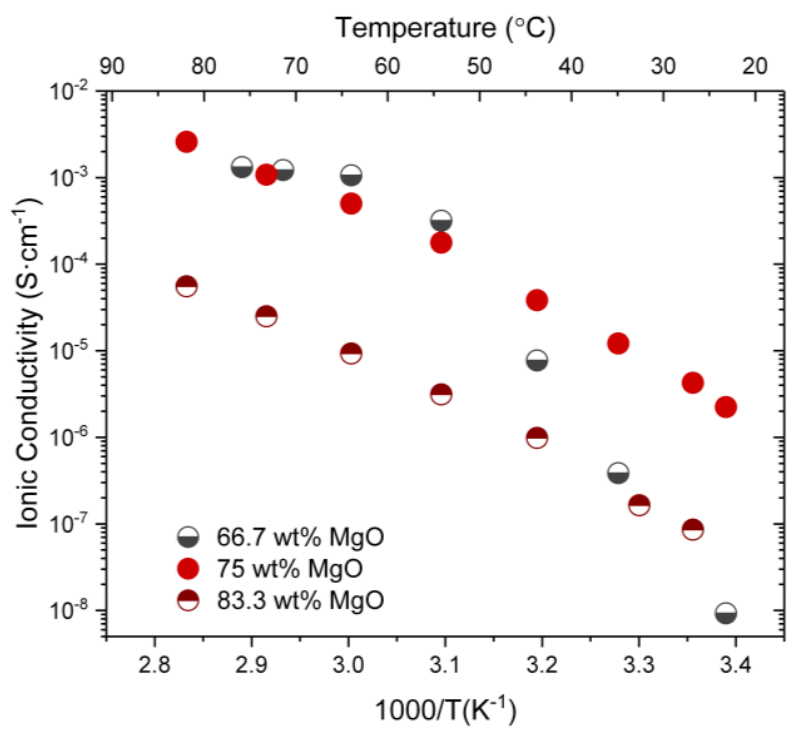

Figure S16. Magnesium conductivity as a function of temperature for mixtures of $\mathrm{Mg}\left(\mathrm{BH}_{4}\right)_{2} \cdot 1.6 \mathrm{NH}_{3}$ with addition of different amounts of $\mathrm{MgO}$ nanoparticles. The optimal conduction property was achieved with addition of $75 \mathrm{wt} \% \mathrm{MgO}$. 


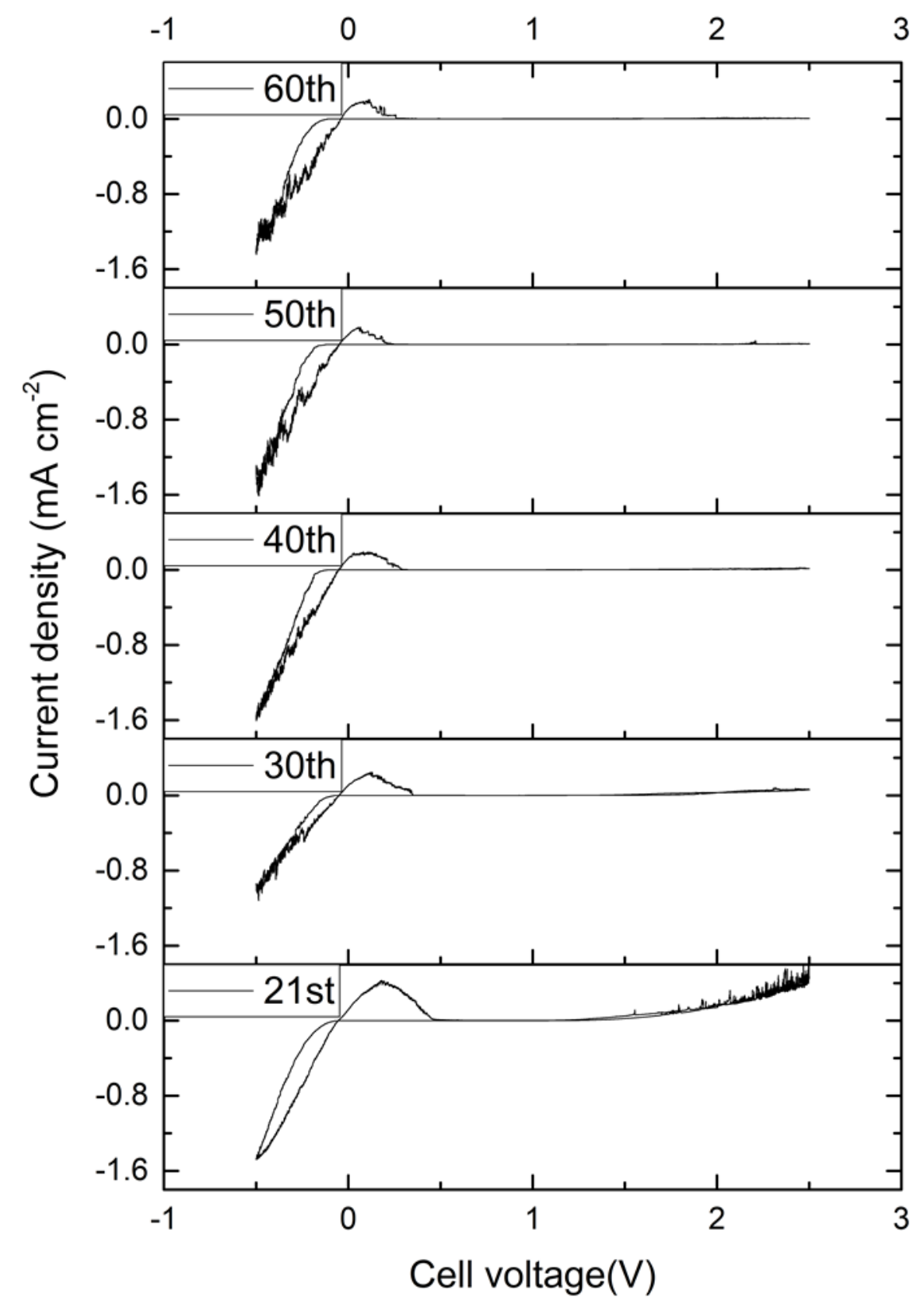

Figure S17. Cyclic voltammogram of an $\mathrm{Au}\left|1.6 \mathrm{NH}_{3} @ \mathrm{MgO}\right| \mathrm{Mg}$ cell at $60{ }^{\circ} \mathrm{C}$ between -0.5 to $2.5 \mathrm{~V}$. Scanning rate: $10 \mathrm{mV} / \mathrm{s}$. This measurement started right after 20 cycles of striping/plating at a scanning rate of $10 \mathrm{mV} / \mathrm{s}$ between -0.5 to $1.2 \mathrm{~V}$. 